\title{
2021 Handbook of Florida Water Regulation: Comprehensive Environmental Response, Compensation, and Liability Act [Superfund] ${ }^{1}$
}

\author{
Michael T. Olexa, Tatiana Borisova, and Jana Caracciolo
}

\section{Preface}

This handbook is designed to provide an accurate, current, and authoritative summary of the principal federal and state (Florida) laws that directly or indirectly relate to agriculture. This handbook provides a basic overview of the many rights and responsibilities that farmers and farmland owners have under both federal and state laws as well as the appropriate contact information to obtain more detailed information. However, the reader should be aware that because the laws, administrative rulings, and court decisions on which this handbook is based are subject to constant revision, portions of this publication could become outdated at any time. Several details of cited laws are also left out due to space limitations. This handbook is provided as an educational text for those interested in water use and water resource issues in Florida.

This handbook is distributed with the understanding that the authors are not engaged in rendering legal or other professional advice, and the information contained herein should not be regarded as a substitute for professional advice. This handbook is not all inclusive in providing information to achieve compliance with the federal and state laws and regulations governing water protection. For these reasons, the use of these materials by any person constitutes an agreement to hold harmless the authors, the UF/IFAS Center for Agricultural and Natural Resource Law, and UF/IFAS Extension for any liability claims, damages, or expenses that may be incurred by any person as a result of reference to or reliance on the information contained in this handbook. Note: UF/IFAS is the acronym for University of Florida, Institute of Food and Agricultural Sciences.

\section{CERCLA Overview}

The Comprehensive Environmental Response, Compensation, and Liability Act (CERCLA, or Superfund) was passed in 1980 and was amended in 1986 by the Superfund Amendments and Reauthorization Act (SARA) and in 2002 by the Small Business Liability Relief and Brownfields Revitalization Act ("Brownfields Amendments"). CERCLA empowers and provides a trust fund for the federal Environmental Protection Agency (EPA) to investigate and to clean up sites contaminated by hazardous substances. CERCLA is a potent measure for forcing responsible parties to contribute to the costs of cleanup (liability for site pollution is extended to several tiers of potential defendants at once; see section titled "Who is liable for cleanup costs under CERCLA" below).

1. This document is FE584, one of a series of the Food and Resource Economics Department, UF/IFAS Extension. Original publication date October 1998. Revised June 2017 and April 2021. Visit the EDIS website at https://edis.ifas.ufl.edu for the currently supported version of this publication.

2. Michael T. Olexa, professor, Food and Resource Economics Department, and director, UF/IFAS Center for Agricultural and Natural Resource Law, and member of The Florida Bar; Tatiana Borisova, associate professor, Food and Resource Economics Department; and Jana Caracciolo, student, Levin College of Law; UF/IFAS Extension, Gainesville, FL 32611.

The Institute of Food and Agricultural Sciences (IFAS) is an Equal Opportunity Institution authorized to provide research, educational information and other services

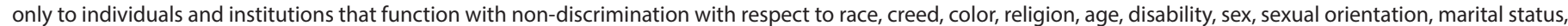

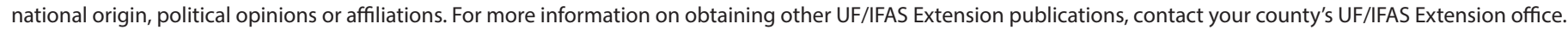
U.S. Department of Agriculture, UF/IFAS Extension Service, University of Florida, IFAS, Florida A \& M University Cooperative Extension Program, and Boards of County Commissioners Cooperating. Nick T. Place, dean for UF/IFAS Extension. 
EPA has created a list of "hazardous substances" that are within the reach of CERCLA regulation. In addition, CERCLA includes by reference all hazardous substances or hazardous pollutants that are identified by the federal Resource Conservation and Recovery Act (see FE583, RCRA), Clean Air Act, and Clean Water Act (see FE582, CWA). The only express exclusions from CERCLA coverage are petroleum (although EPA reserves the power to classify specific petroleum products as hazardous) and natural or synthetic gas.

EPA uses a Hazard Ranking System (HRS) to assess the potential impact a waste site can have on human health and the environment. HRS assists EPA in identifying what CERCLA-financed remedial actions may be necessary. HRS operates on a numerical-based system to determine which uncontrolled waste sites should be placed on the National Priorities List (NPL) for long-term remedial action financed under CERCLA.

HRS assigns numerical values based on the following three factors:

1. likelihood that a site has released or has the potential to release hazardous substances into the environment

\section{2. characteristics of the waste (e.g. toxicity and waste} quantity)

3. people or sensitive environments (targets) affected by the release

\section{Who enforces CERCLA?}

EPA is the chief enforcer of CERCLA. Note that EPA must consult with the relevant state and local officials before deciding on remedies for pollution at federal facilities, especially where the facilities or the remedies chosen fall within the reach of state environmental law.

\section{Who investigataes CERCLA violations?}

The EPA Administrator has authority to begin investigations whenever a release of hazardous substances has occurred or if there is a substantial threat of a release presenting an imminent and substantial danger to public health and welfare. EPA, or a state or local authority acting under agreement with EPA, may require the person or entity under investigation to provide information about the nature and handling of all hazardous materials on the site as well as information related to the subject's ability to pay for the cleanup.
CERCLA also authorizes EPA officials to enter, at reasonable times, any site that has ever had hazardous materials, and further authorizes EPA officials to take samples from the site. If EPA requests are denied during the investigation phase, EPA may issue compliance orders to compel cooperation. EPA can enforce these orders with civil fines of up to $\$ 25,000$ per day.

\section{What are the whistleblower provisions/ rewards under CERCLA?}

CERCLA also authorizes EPA officials to enter, at reasonable times, any site that has ever had hazardous materials, and further authorizes EPA officials to take samples from the site. If EPA requests are denied during the investigation phase, EPA may issue compliance orders to compel cooperation. EPA can enforce these orders with civil fines of up to $\$ 25,000$ per day.

\section{What does CERCLA cleanup involve?}

If the investigation confirms that a hazardous substance (or a pollutant or contaminant with the potential to pose an imminent threat to public health) has been released or may be released, EPA may exercise any combination of several response options. These options include removal action, remedial action, or enforcement. A removal action is an immediate interim intervention. A remedial action is a more permanent measure. Permanent, cost-effective measures are encouraged by CERCLA wherever possible. Also, for the enforcement, the cleanup must be in accordance with other appropriate federal or state environmental acts. EPA, or the state in many cases, is empowered to undertake the cleanup although the responsible parties may be permitted to begin a private cleanup if they can demonstrate to EPA that it will be as effective as the proposed EPA measures. This option may be much less costly for parties who would otherwise be forced to pay for an EPA cleanup.

\section{Who is liable for cleanup costs under CERCLA?}

CERCLA is aimed at five types of potentially liable parties (also known as potentially responsible parties) as follows:

1. Current or past owners of sites

2. Operators of sites

3. Transporters of hazardous substances

4. Arrangers (those who arrange for transportation) of hazardous substances 


\section{Generators of hazardous substances}

For the specific EPA requirements for each of these potentially liable parties under CERCLA, see FE612, Hazardous Waste Management.

CERCLA imposes strict liability and therefore does not require a specific finding of negligence before penalties may be imposed. Also, joint and several liability allows EPA to force a party who may be responsible for only part of the damage to pay the entire cost of cleanup (the rule of joint and several liability is explained more fully in FE598, Private Regulation).

\section{What are transfers of liability?}

It is important to note that site owners may be held liable even if they purchased land without knowledge that hazardous waste was buried there. This has been a source of great concern to land buyers, banks (banks may be liable for the cleanup of properties they foreclose on), and others on the verge of acquiring land.

CERCLA discusses potential risk and liability sharing and transferring agreements between and among parties (e.g., between seller and buyer of a property). First, we define a few legal terms:

- An indemnification agreement is a mechanism to transfer risks from one party to another party

- A hold harmless agreement, sometimes referred to as a release agreement, is signed to release a party (or parties) from legal claims (e.g., when one party agrees not to sue the other party).

CERCLA contains somewhat contradictory language related to the transfer of liability for releases or potential releases of hazardous substances from the potentially responsible parties to any other parties, on one hand, prohibiting transfer of liability, and on the other hand, allowing agreements:

"No indemnification, hold harmless, or similar agreement or conveyance shall be effective to transfer from the owner or operator of any vessel or facility or from any person who may be liable for a release or threat of release under this section, to any other person the liability imposed under this section. Nothing in this subsection shall bar any agreement to insure, hold harmless, or indemnify a party to such agreement for any liability under this section" (CERCLA, Section 107(e)(1)).
To understand this rule, one must look at judicial interpretations of the rule. Courts generally allow indemnity (liability transferring) agreements when these agreements are very specific (narrowly drafted). For example, courts have allowed indemnity agreements for the transfer of liability where the agreement clearly indicated the extent of responsibility bared upon the potentially responsible party. Therefore, narrowly construed indemnity agreements that indicate the extent of liability are generally allowed.

Release and hold harmless agreements are also generally allowed by courts because there is not shift of liability under such agreements. Instead, release and hold harmless agreements acknowledge that one party has waived its right to sue another party and there is not a transfer of liability so it does not apply to $107(\mathrm{e})(1)$.

\section{What are the defenses to liability under CERCLA?}

Defenses to liability are limited to the following:

- Acts of God

- Acts of war

- Actions or omissions of a third party neither employed by nor in a contractual relationship with the defendant

- Innocent landowner defense

- Security interest exemption

- The application and disposal of pesticides registered under the Federal Insecticide, Fungicide, and Rodenticide Act (FIFRA)

- Contiguous property owner exemption (next door or neighboring property owners)

- De micromis exemption

- Federally authorized renovation of a brownfield (contaminated) site

The third party defense is usable only where someone else is entirely responsible for the damage and where there is no contractual relationship between the defendant and the third party. The innocent landowner defense applies when a new landowner through reasonable due diligence did not know, and had no reason to know, that a previous landowner had contaminated the property. In many cases, liability can be placed on both the present and past owners irrespective of actual guilt. The security interest exemption protects lenders (e.g., banks) from liability when the lender does not participate in the management of the facility. Persons who apply pesticides that are registered under FIFRA will be exempt from liability under CERCLA only if 
the pesticides are applied according to the labeling instructions. Also, farmers who dispose of their own pesticides are exempt from CERCLA requirements governing generators as long as they comply with the disposal instructions on the pesticide label and as long as they triple-rinse each container.

Under the contiguous property owner exemption, owners of land that borders or is located near the contaminated land/site which is or may be contaminated by the release of hazardous substances on the neighboring site do not fall under the category of owners or operators and are exempt from liability as long as the owners do all of the following:

- Do not cause, contribute to, or consent to the release or threatened release of hazardous substances.

- Are not potentially liable or affiliated with a potentially liable party through any direct or indirect familial relationship, or any contractual, corporate, or financial relationship not based on the sale of goods or services, or the result of a reorganization of a business entity that was potentially liable.

- Take reasonable steps to stop any continuing release, prevent or limit human or environmental exposure to the hazardous substance released from the contaminated site, and cooperate with EPA.

Under the de micromis exemption, arrangers (those who arrange for the transportation of hazardous substances) or transporters (those who transport hazardous substances) are not liable for the cleanup costs of the contaminated site as long as they can demonstrate that the amount of the hazardous substance they arranged to be transported or did transport was less than 110 gallons of liquid materials or less than 200 pounds of solid material and that all or part of the disposal, treatment, or transport occurred before April $1,2001$.

\section{What is Brownfield redevelopment?}

Under the brownfield exemption, persons or private entities purchasing known or suspected brownfield sites for renovation as business complexes, open public parks, etc. will not be liable for the cleanup of contamination on the site unless they cause the release (i.e., pouring out the contents of drums while clearing the site). These owners must clean up the site to an acceptable lower standard than that mandated by CERCLA.

If a developer qualifies, both the federal and state governments have programs (in Florida it is the Brownfields Redevelopment Act) that provide grants to help redevelop contaminated sites. For a list of federal grant qualifications and an application, please contact EPA.

Under the Florida Brownfields Redevelopment Act (BRA), the state government will provide incentives for the redevelopment of brownfield sites in Florida under certain terms and requirements.

The local government with jurisdiction over the brownfield site must notify the Florida Department of Environmental Protection (FDEP) of its decision to designate the site for $\mathrm{BRA}$ rehabilitation. Along with the requirements that the local government must give notice of the designation to citizens and must provide the opportunity for citizens to be heard concerning the designation, BRA further requires that the local government, in determining the areas to designate as brownfield sites, use factors including:

- Whether the site has reasonable economic potential

- Whether the site has the potential to attract private sector participation in rehabilitating the site

- Whether the site contains areas suitable for limited recreational space, or cultural or historical preservation purposes

In addition, in order to qualify under BRA, the site must not be subject to an ongoing formal enforcement or corrective action pursuant to federal authority including but not limited to CERCLA, SWDA, CWA, or RCRA.

The BRA offers many incentives to those who redeveloped brownfield sites. Some of these incentives include:

- Tax exemptions

- Grants, including community development block grants

- Zoning incentives

Just as the federal programs do, BRA requires that the brownfield site be cleaned up according to specific criteria. For a list of BRA cleanup criteria and for more information on the terms and requirements of BRA, please contact FDEP.

\section{What are environmental audits?}

An environmental audit is basically an evaluation of the land's condition and an appraisal of the consequent likelihood that the lender or new property owner will become subject to some type of enforcement lien to secure funds for future cleanup costs at a waste site that might impair the lender's security. A lien is a legal interest that a creditor, in this case the federal government, takes in a person's 
property to secure payment of a debt. Such a lien might arise, for example, from the liability CERCLA imposes on owners for hazardous substances buried on their land. CERCLA can threaten innocent buyers because it applies even if the pollution were left by a previous owner and the buyer had no knowledge of it. If the audit reveals that the land is in some way "unclean" the purchase transaction will inevitably be delayed until the lender is reassured that its interest in the land will not be devalued. An environmental audit, preferably one performed on the land before it is purchased, will help to satisfy the reasonable due diligence standard of the innocent landowner defense against liability under CERCLA.

\section{What are the penalties under CERCLA?}

Under CERCLA, prompt notification to EPA is required after any spill or release of hazardous substances into the environment. CERCLA also requires that the location of any site containing hazardous materials be reported to EPA. Failure to report in either case may result in fines and/or imprisonment for up to five years.

Along with the costs (which can be high) of cleaning up the contaminated site, the potentially liable parties (also known as potentially responsible parties, or PRPs) may also be assessed a fine of no more than $\$ 25,000$ per violation. These violations include failure to report to EPA any spill or release of hazardous substances into the environment, destruction of records pertaining to the release of hazardous substances and contamination of the site, and violations of settlement agreements. If the violation continues, the potentially liable parties will be assessed a fine of no more than $\$ 25,000$ a day for each day the violation continues. In the case of subsequent violations, the fine may be increased to $\$ 75,000$ a day for each day the violation continues. Also, CERCLA has a citizen lawsuit provision under which a person may sue the potentially liable parties for any personal injury or property damage caused by the release of the hazardous substance.

\section{Sources}

42 United States Code, Sections 9601 to 9675

Chapter 376, Florida Statutes, Sections 376.77 to 376.85

For further information about the HRS, please consult the EPA website (https://www.epa.gov/superfund/ introduction-hazard-ranking-system-hrs).

\section{Acknowledgments}

The authors are indebted to the personnel of both state and federal agencies who provided their time and advice in the preparation of this handbook. We acknowledge Carol Fountain and Susan Gildersleeve at the University of Florida for their assistance in editing this handbook. We also acknowledge funding received for updating this publication from the James S. and Dorothy F. Wershow UF/ IFAS Center for Agricultural and Natural Resource Law Endowment. 